\title{
Reflection of People Ethical Ideas in Proverbs and Sayings
}

\author{
Gulipa Madmarova1, Mavliuda Rozykova², Gulsana Abytova ${ }^{3}$, Gulmira Imasheva², \\ Gulmira Kadyrova ${ }^{2}$, Kanymzhan Murzakulova ${ }^{1}$, Ainura Kydykeeva ${ }^{2}$, Samargul Aitieva1, \\ Dinara Surkeeva4 ${ }^{4}$, Zhypargul Abdullaeva ${ }^{5^{*}}$ (D)
}

\author{
${ }^{1}$ Department of Russian Language Practical Course and Speech Culture, Osh State University, Osh, Kyrgyzstan \\ ${ }^{2}$ Department of Interfaculty Russian Language, Osh State University, Osh, Kyrgyzstan \\ ${ }^{3}$ Department of World Literature, Osh State University, Osh, Kyrgyzstan \\ ${ }^{4}$ Department of Germanic Philology, Osh State University, Osh, Kyrgyzstan \\ ${ }^{5}$ Science and Research Department, Osh State University, Osh, Kyrgyzstan \\ Email: *jypar.science@oshsu.kg
}

How to cite this paper: Madmarova, G., Rozykova, M., Abytova, G., Imasheva, G., Kadyrova, G., Murzakulova, K., Kydykeeva, A., Aitieva, S., Surkeeva, D., \& Abdullaeva, Z. (2021). Reflection of People Ethical Ideas in Proverbs and Sayings. Open Journal of Modern Linguistics, 11, 440-447.

https://doi.org/10.4236/ojml.2021.113033

Received: May 28, 2021

Accepted: June 22, 2021

Published: June 25, 2021

Copyright $\odot 2021$ by author(s) and Scientific Research Publishing Inc. This work is licensed under the Creative Commons Attribution International License (CC BY 4.0).

http://creativecommons.org/licenses/by/4.0/

\begin{abstract}
Each nation has its own ethical views, as 90 percent of these ideas coincide among different peoples, and they are remaining as 10 percent including specific concepts that are determined by the way of life, geographic location, history, religion, etc. Many scientists and philosophers have written about ethics, from antiquity to the present day. It is ethics that makes it possible to highlight the moral values of the people, which are passed on from generation to generation. Absolutely all ethical values are reflected through the language of the people, which conveys them in their proverbs, sayings, phraseological units, and catchphrases. Language can be compared to a piggy bank that accumulates all cultural values: in paremias, in folklore, fiction, poetry, etc. Proverbs and sayings of any nation are the results of their mental activity since their generations. They generalize people's experience in the form of complete judgments, conclusions, teachings and figuratively defined objects, events and phenomena. Models for constructing proverbs and sayings are similar for most people. Their semantic content is also very similar since people's spiritual values in different nationalities for the most part coincide. Based on this, we have the opportunity to explore the specifics of a particular people, expressed in their language linguistic units. Only by mastering the native language, a person becomes the bearer of his own national culture, all linguistic units of which contain national and cultural information.
\end{abstract}

\section{Keywords}

Ethics, Paremia, Proverbs, Concept, Sayings, Culture, Morality 


\section{Introduction}

Ethics from the Greek ethos mean temper, custom, the science of morality. Even Aristotle (Papouli, 2019) introduced the term "ethical" to highlight a special class of human qualities, such as kindness, courage, moderation, generosity, etc., which differ significantly from the people's mind and emotional expression quality. He called the word "ethics" as ethical virtue, the theory that studies ethics, as well as books that set out the ethical theory (Santas, 1996). The original meaning of the word ethos was determined as "shared and rules generated by such a community; norms that unite society, overcoming individualism and aggressiveness". As society develops, the study of conscience, good and evil, sympathy, friendship, the meaning of life, self-sacrifice, etc., added to this meaning. The concepts developed by ethics are kindness, mercy, justice (Couenhoven, 2020), friendship, solidarity and others, which guide the moral development of social institutions and relations. In science, ethics is understood as the field of knowledge, and morality and what it studies, i.e. object of ethics. The main problems of ethics are the problems of the criteria of good and evil (Bastian et al., 2015), virtue and vices; life meaning problems and the purpose; the problem of free will (Shepherd, 2015).

Natural necessity is the same everywhere, but the laws, customs, manners of people are diverse and changeable. That is why it became possible to compare different laws and customs. The choice between cultural institutions, which differ among different peoples, and also change from generation to generation, turned out to be dependent on their justification. Therefore, we can conclude that ethics is inseparable from philosophy. According to the Aristotle, the goal of ethics is not knowledge, but action; the so-called "golden rule" of ethics "do not do to others what you do not wish for yourself" existed in one form or another independently in different cultures also it is present in Confucius (Gensler, 2013; Yao, 2017; Saukov, 2017; Avci, 2017).

Ethics explores what is valuable in life and the world since ethical behavior is the realization of ethical values. These values can be seen both, in all and individual situations. Ethics contributes to the formation's ability to analyze and evaluate actions. Currently, ethics, the ethical conviction in human life is carried out with great difficulty. Modern man is in a hurry all the time, and has no time to think over his actions. And an ethical person is one who understands the value of life. An important role in this is played by the will of a person, aimed at comprehending the value and contributing to the achievement of these values in life.

Ethical values are arranged in a hierarchical ladder, a kind of "pyramid" of values, the basis of which is formed by the unconsciously realized values of life (the will to live, the need for food, etc.), at the top of which is the highest conceivable value (Elishev, 2011). Ethical values are values of belief and behavior. In the evaluating consciousness of a person and society, new values constantly appear, while others drop out. A hundred years ago it was highly moral and good, 
today can be immoral and evil. Each person has his own "pyramid" of values, the basis of which is belonging to any nation. The group of values, united in this basic essence, creates morality. The realization of values consists of following demands that come from value and subordinating everyday life to people's demands; for example, not only recognizing honesty as a virtue but consistently acting following this moral value. In situations of daily life, a person can usually choose between several values.

The direct embodiment of people's ethical ideas was found in language. Outside of language, culture is simply impossible, since language forms its foundation, its internal basis. Through language, people convey and fix symbols, norms, customs, convey information, scientific knowledge and models of behavior, beliefs, ideas, feelings, values, attitudes. This is how socialization takes place, which is expressed in the assimilation of cultural norms and the development of social roles, without which a person cannot live in society.

\section{Materials and Research Methods}

The research materials from the dictionaries of proverbs and sayings of the Russian and Turkic (Kyrgyz, Uzbek) languages, Internet data were used. The main methods applied such as the comparative method with the classification of materials, the analysis of dictionary definitions, the method of contextual analysis of lexical units, and the method of continuous sampling of proverbs with the concepts of good and evil was also used. The contrastive linguistics based on the comparative method, where mainly the material classification, analysis of dictionary definitions, the method of contextual analysis of lexical units performed.

\section{Results and Discussions}

Based on research analysis such as comparative method with the classification of materials, the following results were obtained:

1) Ethics that dictate what is a value in life and the world, since ethical behavior is the realization of ethical values in life;

2) The main problems of ethics is the problem of the criteria of good and evil, virtue and vices; the problem of the meaning of life and the purpose of a person; the problem of free will;

3) The specificity of the culture of the Russian and Kyrgyz peoples is directly reflected in the proverbial fund of the languages under consideration;

4) All concepts denoted by paremias are equally familiar to the speakers of the Russian and Kyrgyz languages, but the images underlying the meanings are specific;

5) Exploring the conceptual sphere of the good/evil opposition, we can trace the worldview of an ethnos, its stereotypes and priorities;

6) The process of a person's cognition of the world around him, his familiarization with the concepts of morality and ethics occurs only in the process of mastering the language and through it. 
Language is compared to the treasury, to a storeroom, to a bank of culture. It preserves cultural values in vocabulary, grammar, idioms, proverbs, sayings, in folklore, in fiction and scientific literature, in the forms of written and oral speech (Poshtareva, 2005). Thanks to language, consistency, harmony and stability are achieved in society.

For example, the proverb "Better to be distressed than to distress" says that suffering yourself is easier than causing suffering to another (Pogrebnyak \& Wan, 2016). Ethics assumes that a person has a choice, i.e. freedom to decide one direction or another. According to ethics, a person acts ethically correctly if he realizes the value that requires the greatest moral strength for its implementation. The required strength indicates that a given value (for a given individual) takes on more importance than other values from which he can choose. The realization of values, which are recognized as the highest, depending on the circumstances, is good; the implementation of any low-standing value is evil. The torment of a person himself is a higher moral value than the torment inflicted on someone. This choice is considered ethically correct, i.e. he is good. If we make a different choice and prefer to torture another person, then our choice is evil according to the generally accepted scale of ethical values.

In proverbs with the meaning "What is hello, so is the answer", a person also has the right to choose: to do good or bad deeds. There are many such proverbs in all languages: As you will regale, people will spout you (Russian);

Whoever digs a hole on people falls into it himself (in Ukrainian);

If you behave with the good, you will take over the good; if you behave with the bad, you will take badly (Kyrgyz, Uzbek);

As you go to bed, you will sleep (Latvian);

As it comes around, it will respond (Russian);

Whatever cup you pour for a friend, you can drink it yourself (Belarusian).

Proverbs teach people to make the right choice, not to wish someone evil, not to commit evil deeds, to distinguish between good and evil.

\subsection{Concept Good and Evil}

The concepts of good and evil are one of the key concepts of the linguoculture of any nation. Exploring the conceptual sphere of this opposition, we can trace the worldview of the ethnos, its stereotypes and priorities. National folklore art reflects moral and moral values, way of life, way of life, character, traditions and customs of the people. Proverbs and sayings are one of the most ancient and widespread genres of folklore. This is what Dahl wrote about the proverbs: "The greatest wealth of the people is language! And, perhaps, in none of the forms of the linguistic creativity of the people with such force and so many-sided does not manifest its mind, so crystalline is its national history, social order, everyday life, worldview, as in proverbs." (Gafarova, 2017) Proverbs are one of the important components of the national heritage, a living heritage accumulated by the people over the centuries. They help to better know the character and spirit of the people, which is extremely important for mutual understanding and the estab- 
lishment of friendly relations between different ethnic groups. That is why it is important to know and understand proverbs and sayings in a deep and comprehensive study of the language.

\subsection{Proverbs}

National-cultural semantics is present at all levels of the language: both in grammar and in syntax, not excluding phonetics (Negmatova, 2010). Proverbs context composed in the paremia with a special independent context having direct and figurative meaning itself as a part of the context (Sergienko, 2010). Proverbs and sayings are sentences meeting syntactic rules: they have the same word order, are constructed according to the structure of simple or complex sentence (Radjabova, 2016). Proverbial sayings are always signs and at the same time models of various typical situations and relationships between things or phenomena in real life. The true theme of any proverb or saying is not this or that word, not this or that thought, and not even this or that area of human activity, but "some invariant pair of opposed entities, to which the meaning of using images in this proverb is reduced" (Permyakov, 1988). On this basis, paremiology identifies constructive types of invariant pairs of opposed phenomena:

1) Contrast of different sides of one object: beginning-end, content-form, wholepart, top-bottom, etc.

2) The opposition of physically different objects: healthy-sick, good-bad, old-new, big-small, etc. In proverbs and sayings, the system of binary oppositions is most concentrated. Each proverb can be interpreted as a choice between two alternatives.

Representatives of different ethnic groups (nationalities, nations, races, etc.) think logically in one way or another in the same way. This unifying feature of the peoples is especially evident in the paremias. Proverbs and sayings of the peoples of the world are based on approximately similar principles and patterns. For example, we consider the schemes of proverbs about good and evil as following:

I. To do what (to whom, why, etc.):

1) Do good and fear evil (Hindi).

2) Do good and don't ask who it is for (Colombian).

3) Do Good and Fear Nothing (Portuguese).

4) Do Good in the Face of Evil (Irish).

5) Do good, and you will find only good (Moorish).

6) Do good to the one who harms you (Sierra).

7) Do good at least out of imitation (Japanese).

8) Do good while it is hefty: there will be no time after death (Slovenian).

II. What is that...

1) Evil is a Bad Counselor (Hungarian).

2) Evil on the mind - a load on the back (Akan).

3) Anger and Evil are Siblings (Chinese).

III. If, then...

1) If a person cannot be beautiful and rich, as he would like, then he can be 
kind and honest (Serbian).

2) If they paid for goodness with goodness, they would not have slaughtered the old bull (Turkish).

3) If you do a bad thing, he will not understand, if you do evil to a good one, he will not forgive (Kalmyk).

4) If you repay good for good, then well done, if you answer for evil with good, then sage (Kyrgyz). Due to the universality of semantics and structure, proverbs and sayings contribute to the recreation of universal, regional and national pictures of the world, at the same time emphasizing the peculiarities of the people's thinking, their centuries-old human experience and ideas about the world and generally accepted ethical norms.

\subsection{Understanding Good in Russian Language}

In Russian linguoculture, the concept of good includes the following concepts: positive moral values (counterbalance to the concepts of evil, bad); good deed, benefit; good relationship; the positive quality of someone or something (good person, good book); material well-being (making good); everything that is associated with happiness, joy, love, goodness and causes a positive assessment in people.

The Russian people, like many Europeans, usually associate well with light and whiteness, and evil with darkness and blackness. In Russian culture, the word good originally means material property. A "good man" is a rich man. A fat person who was able to gain weight due to the fact that he could afford to buy groceries is called "kind", "plump". Kindness is a character trait that allows a person to share his goodness, property. With the advent of Christianity, the concept of good acquired as a slightly different meaning: moral values, good, etc.

In the Turkic linguistic culture, the conceptual sphere of good/zhakshylyk includes the following concepts: a good deed, a benefit; good quality of someone or something; good, good deed; holidays; happiness joy.

\subsection{Understanding Good in the Kyrgyz Language}

The Kyrgyz, for example, believed that not everyone can get good; it must be earned by good deeds, a good disposition, and a righteous life. It is impossible to force someone to do good, it must be done only voluntarily, otherwise, this goodwill loses its value. If we talk about the color designation, then among the Turks, not always light is good, and dark is bad. Black eyes, hair is a sign of beauty, and light is a sign of non-compliance with the generally accepted standard. For example, kara koz, kara chach are positive epithets that can also act as a proper name. Kok Koz, sary chach negative epithets such as a nicknames.

In the kingdom of ethically significant values, there are: 1) the main human values, which, to a greater or lesser extent, are included in all other ethical values (values of life, consciousness, activity, suffering, strength, free will, foresight, purposefulness); 2) virtues (justice, wisdom, courage, self-control, love for one's 
neighbor, truthfulness and sincerity, loyalty and devotion, trust and faith, modesty and humility, the value of treating others; 3) more private ethical values (love for the most distant, ability to give others their spiritual wealth, personal values, love aimed at the ideal value of someone else's personality).

Thus, paremias reflect ethical values on the example of the phenomena of reality that have been observed by people since ancient times and therefore are part of the collective experience of the people. According to A.V. Artemova, proverbs and sayings "do not reflect a fragment of reality, but a rethought concept of the phenomena of the real world. All their meanings are associated with a person, his perception of the world and attitude to reality" (Artemova, 2000).

\section{Conclusion}

One of the proverb features is to deliberate on reference in folk experience. This is how it differs from other semantic units of the language, which represent such an unconscious use of the experience in previous generations (Anichkov, 1997). Thus, when the proverb is used, the problem of the truth in the statement is removed, "since a person speaks not from himself, but referring to someone else's and thus objectified experience" (Nikolaeva et al., 1994). That is why, after examining the proverbs and sayings of different peoples, we can talk about mental specifics of the national thinking in the Russian or Turkic peoples, about the features of their moral and ethical views. We can judge the peculiarities of ethical values of people by studying the cultural heritage of this or that ethnic group and proverbial expressions play a significant role.

\section{Conflicts of Interest}

The authors declare no conflicts of interest regarding the publication of this paper.

\section{References}

Anichkov, I. E. (1997). Idioms and Semantics. Questions of Linguistics, 5, 140-150.

Artemova, A. V. (2000). Emotive-Evaluative Objectification of the Concept "Woman" in the Semantics of Phraseological Units (Based on the Material of English and Russian Phraseology). Thesis, Pyatigorsk: Pyatigorsk State Linguistical University.

Avci, E. (2017). A Normative Analysis to Determine the Goals of Ethics Education through Utilizing Three Approaches: Rational Moral Education, Ethical Acculturation, and Learning throughout Life. International Journal of Ethics Education, 2, 125-145. https://doi.org/10.1007/s40889-017-0032-4

Bastian, B., Bain, P., Buhrmester, M. D., Gómez, Á., Vázquez, A., Knight, C. G., \& Swann, W. B. (2015). Moral Vitalism: Seeing Good and Evil as Real, Agentic Forces. Personality and Social Psychology Bulletin, 41, 1069-1081. https://doi.org/10.1177\%2F0146167215589819

Couenhoven, J. (2020). The Justice in Mercy. Journal of Religious Ethics, 48, 399-417. https://doi.org/10.1111/jore.12320

Elishev, S. O. (2011). Study of the Concepts "Value", "Value Orientations" in an Interdisciplinary Aspect. Values and Meanings, 2, 82-96. 
Gafarova, A. S. (2017). Proverbs vs Sayings. Philological Sciences. Questions of Theory and Practice, 11, 54-57.

Gensler, H. J. (2013). Ethics and the Golden Rule (246 p). Routledge.

Negmatova, M. M. (2010). About Proverbs and Sayings. Bulletin of the Tajik State University of Law, Business and Politics: Humanities Series, 4, 155-159.

Nikolaeva, O. V., Chen, S., \& Panina, M. E. (1994). Cross-Cultural Paremiology: Chinese Proverbs and Sayings in the English-Language Chinese Media. Siberian Journal of Philology, 3, 233-247. https://doi.org/10.17223/18137083/60/20

Papouli, E. (2019). Aristotle's Virtue Ethics as a Conceptual Framework for the Study and Practice of Social Work in Modern Times. European Journal of Social Work, 22, 921-934. https://doi.org/10.1080/13691457.2018.1461072

Permyakov, G. L. (1988). Fundamentals of Structural Paremiology (326 p). Moscow: Nauka.

Pogrebnyak, Y. V., \& Wan, S. (2016). Structural and Semantic Characteristics of the Concept "Shame" in Russian and Chinese Linguocultures (Based on Proverbs, Sayings and Phraseological Units). Bulletin of the Volgograd State Pedagogical University, 9-10, 96-100.

Poshtareva, T. V. (2005). Formation of Ethnocultural Competence. Pedagogy, 3, 35-42.

Radjabova, M. M. (2016). On the Role and Place of Proverbs and Sayings in the Language System. Scientific Notes of the Khujand State University Named after Academician B. Gafurov. Humanities, 3, 163-168.

Santas, G. (1996). The Structure of Aristotle's Ethical Theory: Is It Teleological or a Virtue Ethics? Topoi, 15, 59-80. https://doi.org/10.1007/BF00141306

Saukov, V. A. (2017). Ethics of Aristotle as a Means of Forming a Civil Society. Materials of the All-Russian Scientific and Practical Conference "Science and Society", No. 1, 138-141.

Sergienko, O. S. (2010). Semantic Transformations of Proverbs Based on the Material of the Czech and Russian Languages. Bulletin of the Leningrad State University. A.S. Pushkin, 1, 280-289.

Shepherd, J. (2015). Consciousness, Free Will, and Moral Responsibility: Taking the Folk Seriously. Philosophical Psychology, 28, 929-946.

https://doi.org/10.1080/09515089.2014.962018

Yao, X. (2017). Reconceptualizing Confucian Philosophy in the 21st Century (460 p). Singapore: Springer. https://doi.org/10.1007/978-981-10-4000-9 